Relations industrielles

Industrial Relations

\title{
Afzalur, Rahim M. and Albert A. Blum, eds, Global Perspectives on Organizational Conflict
}

\section{John Kervin}

Volume 51, numéro 3, 1996

URI : https://id.erudit.org/iderudit/051120ar

DOI : https://doi.org/10.7202/051120ar

Aller au sommaire du numéro

\section{Éditeur(s)}

Département des relations industrielles de l'Université Laval

\section{ISSN}

0034-379X (imprimé)

1703-8138 (numérique)

Découvrir la revue

Citer ce compte rendu

Kervin, J. (1996). Compte rendu de [Afzalur, Rahim M. and Albert A. Blum, eds, Global Perspectives on Organizational Conflict]. Relations industrielles /

Industrial Relations, 51(3), 593-594. https://doi.org/10.7202/051120ar

Tous droits réservés ( Département des relations industrielles de l'Université Laval, 1996
Ce document est protégé par la loi sur le droit d'auteur. L’utilisation des services d’Érudit (y compris la reproduction) est assujettie à sa politique d'utilisation que vous pouvez consulter en ligne.

https://apropos.erudit.org/fr/usagers/politique-dutilisation/ 
En conclusion, l'étude exploratoire de Rodrigue Blouin met en lumière quelques vices de la pensée juridique qui, indéniablement, menacent "l'authenticité " de l'arbitrage. Il faut souhaiter que sa publication marque le point de départ d'un approfondissement de la problématique, en allant au delà de la perception.

GILLES PLANTE

Québec

\section{Global Perspectives on Organizational Conflict}

edited by M. Afzalur RAHIM and Albert A. BLUM, Westport, Conn., Praeger, 1994, 160 p., ISBN 0-275-93828-X (alk. paper).

It's a rare delight to find a fers both sound advice to the practitioner and theoretical insights to the academic researcher. The title and introductory chapter of this work certainly suggest the possibility of such a "double find" within its pages.

As the editors note in their introduction, individuals in business and public administration increasingly deal with their counterparts from other countries, and these dealings sometimes involve conflict. And since different cultures employ different approaches to conflict-resolution, familiarity with cross-cultural variation is undeniably useful to the practitioner involved in cross-national negotiations. In this work, seven different authors discuss conflict management techniques in seven different countries: France, Japan, the Netherlands, Norway, South Africa, Spain, and Turkey. Why these seven? The editors don't tell us. These are not the top U.S. trading partners (both editors teach at U.S. universities). Perhaps they represent a carefully selected "range" of conflict management techniques. Perhaps they represent countries in which the authors had convenient contacts. Who knows? This problem aside, the chapters appear to cover fairly thoroughly, and with some consistency, conflict management within each culture.

Which brings us to the theoretical side. The consistency we find is due to the editors' laying out a comprehensive theoretical framework in which their authors are to discuss each country. Hofstede's four cultural dimensions (power distance, uncertainty avoidance, individualism, masculinity) are used as one of these organizing concepts. Most authors discuss their country's score on each dimension (scores derived form Hofstede's 40-nation survey of employees in a large multinational company). Some (e.g., Rognes in his chapter on Norway) compare scores and the cultural conditions that produce them to those of the U.S. Others (e.g., Munduate, Ganaza, Alcaide, and Peiró writing on Spain) offer a discussion of how Hofstede's scores reflect cultural traditions in their country. Others (e.g., Kozan on Turkey) seem to disregard the editors' intent and largely ignore Hofstede's conceptual dimensions.

A second major organizing principle for che chapters is also theory-based the five dimensions of handling interpersonal conflict originated by Follett, conceptualized by Blake and Mouton, and reinterpreted by Thomas. The authors use the Thomas dimensions, renamed as "concern for self" and "concern for others" to identify the five dimensions: integrating, obliging, dominating, compromising, and avoiding. All authors follow the framework closely, and, with some page-flipping, readers will quickly note interesting comparisons.

Each author was also asked to look at social and economic factors, managerial styles, and alternative dispute management procedures. Particularly in the latter two areas practitioners will find very useful background and ideas. Some authors venture into theoretical directions. Moran, Allen, Wichmann, Ando, and Sasano, writing about Japan, offer a very 
interesting alternative model of managerial styles that is worth further study.

The book lacks an integrating final chapter. Such a chapter would draw comparisons among the countries, point out similarities and differences, and reduce the wealth of practical information to a smaller number of useful theoretical distinctions.

A theoretical problem in this work is that conflict is treated as an undifferentiated construct. There are many different kinds of conflict in organizations: among individual employees, between superiors and subordinates, among departments competing for scarce organizational resources, among groups of employees (perhaps on ethnic or racial lines), between union and management.
Some tighter conceptualizing would help here: different conflict venues likely involve different conflict management procedures. Another problem was pointed out to me by a research assistant who looked over the book - just how valid are the generalizations? Can one really generalize the conflict management techniques of an entire country's business force? What about inter-firm differences, particularly between very large and fairly small companies?

In all, this book is an easy read, but of more use to practitioners than theorists. Oh well, half a loaf... but it's a very good half-loaf indeed!

JOHN KERVIN

University of Toronto

\section{Canadian Auto Workers: The Birth and Transformation of a Union}

by Sam GINDIN, Toronto, Ontario, Lorimer \& Company Ltd Publishers, 1995, $\mathrm{x}, 291$ p., ISBN 1-55028-499-1(bound) and ISBN 1-55028-498-3(pbk).

The Canadian Auto Workers (CAW), the largest private sector union in Canada, has a long and rich history. It also has a mystique in the North American labour movement because of its deep rooted culture of ideological resistance and political activism. The union prides itself on its spirit of independence, innovative bargaining, a tradition of internal democracy and organizational dynamism, and a dedication to social unionism philosophy - a form of "unionism which is rooted in the workplace but understands the importance of participating in, and influencing, the general direction of society." Since its birth in the late 1930s as the Canadian district of the International Union of Automobile Workers of America (UAW) it has bargained hard for better wages and working conditions, and struggled vigorously for stronger legislative protections for workers and a universal social safety net as a "right of citizenship." The union is credited with pioneering a number of collective agreement provisions which have become a stand- ard feature of unionized employment in Canada. Key among these are union security, deferred annual wage increases and a cost of living clause in multi year agreements, paid vacation and holidays, employer financed supplementary unemployment benefits and other income security programs. It broke away from its parent, the UAW, in 1985 and became an independent national union when its leadership concluded that the UAW was losing its ability to act as a social movement and had ceased to be an independent voice of labour by accepting concession bargaining as a "new direction" to help auto employers become competitive. Since the split the CAW has become even more confident of its ability to pursue its distinct path of workplace reforms and social and political change. The exuberance is related to the union's continuing impressive gains at both the collective bargaining table and in the political arena as well as its phenomenal growth over the past ten years due to a series of mergers and aggressive 